\title{
Rare virilizing granulosa cell tumor in an adolescent
}

\author{
DOROTTYA BÚS ${ }^{1}$, MÁRIA BUZOGÁNY ${ }^{2}$, GYÖNGYI NAGY ${ }^{3}$ and GYÖRGY VAJDA ${ }^{1}$ \\ Departments of ${ }^{1}$ Obstetrics and Gynecology, ${ }^{2}$ Neonatology and Pediatrics, \\ ${ }^{3}$ Radiology, Zala County Hospital, 8900 Zalaegerszeg, Hungary
}

Received July 21, 2016; Accepted September 14, 2016

DOI: $10.3892 / \mathrm{mco} .2016 .1084$

\begin{abstract}
Hormone-producing malignancies are rare in children or adolescent patients: Only $0.1 \%$ of all ovarian tumors and $4-5 \%$ of granulosa cell tumors occur in the sexually non-active ages. Granulosa cell tumors (GCTs) are sex cord-stromal tumors of the ovary, representing 7-8\% of all ovarian neoplasms. A total of $95 \%$ of all GCTs are adult-type, and only $5 \%$ are diagnosed as juvenile-type GCT. A majority of children with juvenile-type GCT present with isosexual precocious pseudopuberty due to excessive estrogen production, although virilizing, testosterone-producing, juvenile-type GCTs are rare, occurring only in $2-3 \%$ of cases. The present case study reports on a case of a virilizing, juvenile-type GCT in a 14-year-old girl, along with a review of the literature.
\end{abstract}

\section{Introduction}

Granulosa cell tumors (GCTs) are rare, hormone-producing ovarian malignancies, representing $80 \%$ of ovarian sex cord-stromal tumors, and accounting for $\sim 7-8 \%$ of all ovarian neoplasms (1). Between 2008 and 2012, there were only 451 histologically confirmed cases of sex cord-stromal cell tumors in 18 states of the USA, $67 \%$ of them occurring in Caucasian female patients (2). A review of the Hungarian literature (3-6) revealed that the incidence of diagnosed GCTs is similar to that of the international data; however, there is no relevant Hungarian statistics database regarding sex cord-stromal tumors. The four representative articles presented 120 cases of GCTs between 1960 and 2005, with patients between the ages of 14 and 86 (3-6). No androgen-producing tumors were mentioned, and there was only one article reporting an adolescent case (5).

Adult patients with GCTs usually present with a palpable mass, or with symptoms due to hormone production, including estrogens or androgens, leading to diagnosis at an early stage with a better prognosis (7). Hormone-producing malignancies

Correspondence to: Dr György Vajda, Department of Obstetrics and Gynecology, Zala County Hospital, 1 Zrínyi Miklós Street, 8900 Zalaegerszeg, Hungary

E-mail: drvagy11@gmail.com

Key words: juvenile granulosa cell tumor, virilization, adolescent, ovary are rare in children or adolescent patients: Only $0.1 \%$ of all ovarian tumors and $4-5 \%$ of GCTs occur in the sexually non-active ages (8). A proper bimanual vaginal examination cannot be performed in the majority of adolescent patients, thereby leading to a more difficult differential diagnosis. Signs and symptoms of these tumors are not as specific as the hormone-producing neoplasms in adults; therefore, a more specific investigation is required in such cases. In the present study, the case of an ovarian juvenile-type GCT with androgenic manifestation in a 14-year-old girl is reported, also including a review of the Hungarian and international literature.

\section{Case report}

A 14-year-old girl presented in Zala County Hospital, Zalaegerszeg, Hungary with complaints of secondary amenorrhea over the course of the past 18 months, followed by masculinization. Her menarche was at the age of 10. After one year of normal menstrual periods, the patient experienced irregular menstruation, followed by amenorrhea. The patient's past medical history was unremarkable. Her body mass index was $18.7 \mathrm{~kg} / \mathrm{m}^{2}$, with $25-50 \%$ weight-for-age and $50-75 \%$ height-for-age percentiles. A physical examination revealed prominent hirsutism on the upper lip, thighs with a Ferriman-Gallway score of 20, delayed thelarche and a deepened voice. A pelvic examination revealed an anteflected, normal-sized uterus, a palpable mass of $4 \mathrm{~cm}$ in the right ovarial area and an enlarged clitoris of $5 \mathrm{~cm}$. The patient's vital parameters and other physical findings were normal.

Laboratory findings revealed an elevated plasma total testosterone level of $8.84 \mathrm{nmol} / 1$ (normal: $0.17-2.81 \mathrm{nmol} / \mathrm{l}$ ). The serum levels of dehydroepiandrosterone sulfate, follicle-stimulating hormone, luteinizing hormone, estradiol, progesterone, thyroid-stimulating hormone, prolactin, $\alpha$-fetoprotein (AFP), cancer antigen-125 and cancer antigen-15-3 were within normal limits. A pelvic ultrasonography revealed a well-defined heterogeneous mass of $12 \times 12 \mathrm{~mm}$ within the right ovary measuring $23 \times 16 \mathrm{~mm}$; other findings were normal. Pelvic, retroperitoneal and renal magnetic resonance imaging analyses made with a Siemens Magnetom Avanto ${ }^{\mathrm{TM}}$ MRI scanner demonstrated the presence of a solid lesion in the right ovary of 36x42x45 mm, minor grade hepatosplenomegaly and ascites (Fig. 1). The patient underwent laparoscopic surgery, during which a right-ovarian tumorous mass of $5 \times 4 \mathrm{~cm}$ with abnormal vascularization was encountered. The right and left Fallopian tubes, the left ovary and the uterus appeared to be 

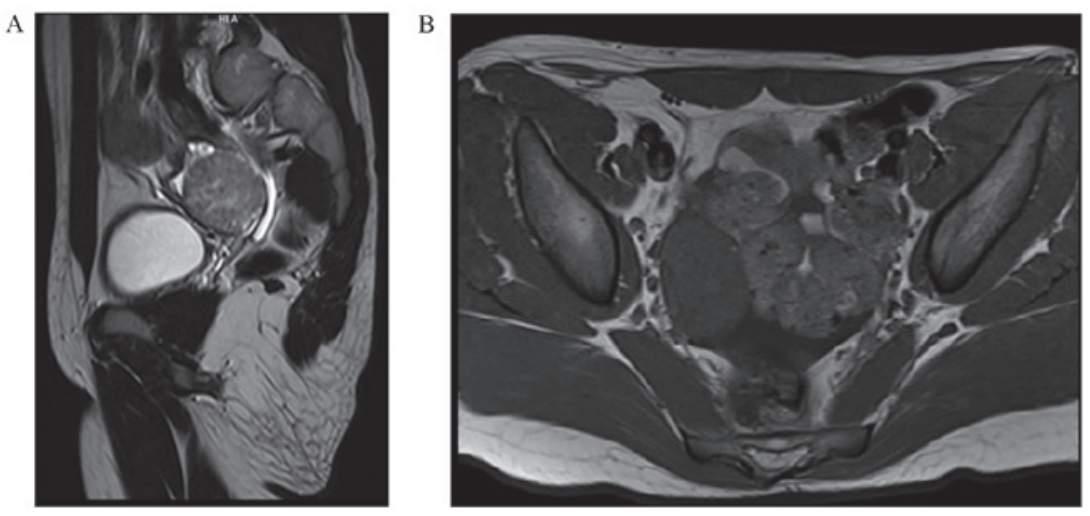

Figure 1. Magnetic resonance imaging findings. (A) T2-weighted MRI of the abdomen (sagittal view) with hyperintense solid laesion in the right ovary. (B) In the T1-weighted image (axial view), the mass is hypointense.
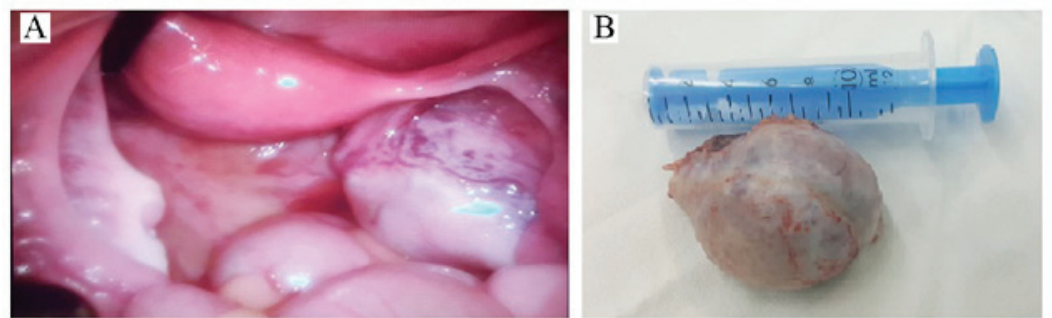

Figure 2. Right ovarian tumor with abnormal vascularization. (A) A representative intraoperative image is shown. (B) An image of the removed ovary.
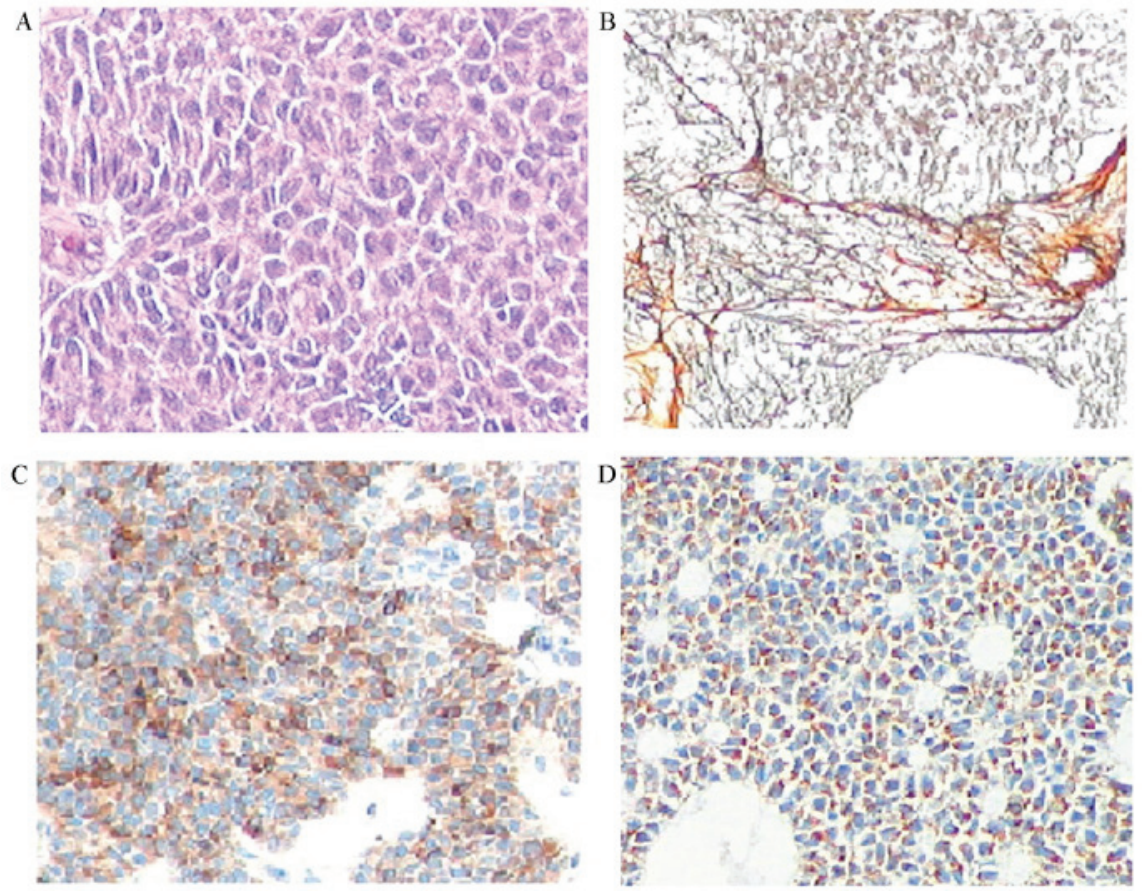

Figure 3. Juvenile-type granulosa cell tumor. (A) Scant cytoplasm and ovoid nuclei in tumor cells (hematoxylin and eosin staining; magnification, x10). (B) Reticular fibers surrounding the tumor nests (silver staining; magnification, x10); (C) inhibin positivity (magnification, x10); (D) Melan-A positivity (magnification, $\mathrm{x} 10$ ).

normal. A right ovarian oophorectomy was performed with a LigaSure $^{\mathrm{TM}}$ device $\left(5 \mathrm{~mm}\right.$ blunt tip, ForceTriad ${ }^{\mathrm{TM}}$ energy platform; Covidien-Medtronic, Minneapolis, MN, USA), and the mass was removed in an Endobag ${ }^{\mathrm{TM}}$ (ASID BONZ GmbH, Herrenberg, Germany) to avoid spreading of the cancer cells.
A histopathological examination confirmed a yellow-tan ovarian mass of $5.5 \times 4 \times 3 \mathrm{~cm}$ with a lobulated cut surface containing a grey-white solid area of $15 \mathrm{~mm}$ (Fig. 2). Microscopic findings revealed the presence of a heterogeneous, solid and cystic tumor with a formation of lobules, nests 
and perivascular palisades of granulosa tumor cells with scant cytoplasm, ovoid nuclei and nuclear grooving in several zones. There was no lymph vascular invasion, and the ovarial serosa was intact.

Immunohistochemical studies (Fig. 3) revealed positive cytoplasmic staining for inhibin and Melan-A, nuclear staining for WT1, nuclear and cytoplasmic staining for calretinin, and membrane staining for CD99. The stain was negative for epithelial membrane antigen (EMA), CD117, placental alkaline phosphatase (PLAP), AFP and CD30. A final diagnosis of juvenile-type GCT was established.

The postoperative course was uncomplicated. Two days after the surgery, the serum total testosterone level had dramatically declined to $0.497 \mathrm{nmol} / 1$. The patient was discharged on the sixth postoperative day. During her follow-up, she got her normal period again, and the 1-week, 1-month and 4-month serum total testosterone levels were $0.50 \mathrm{nmol} / 1,0.41 \mathrm{nmol} / 1$ and $<0.17 \mathrm{nmol} / 1$, respectively.

Prior to the submission of this case study for publication, written informed consent was obtained from the patient's guardian.

\section{Discussion}

GCTs are divided into two histopathological subtypes, classified as adult-type and juvenile-type GCTs. The adult-subtype tumor, representing $95 \%$ of all GCTs, occurs in perimenopausal or postmenopausal women, at a peak age frequency between 50 and 55 years. The juvenile-type GCT is represented in 5\% of cases, mostly recognized in the prepubertal age, at a peak age of 13 (9). The two subtypes may be hormonally active and occur in children, adolescents and adults; therefore, diagnosis is based on a histopathological evaluation (10).

The symptoms of the tumor occur due to its hormone production: Hyperestrogenism in $97-98 \%$ of the cases, and hyperandrogenism in $2-3 \%$ of the cases. Clinical manifestations of estrogen-producing tumors are amenorrhea, dysfunctional menstrual bleeding, growth of uterine leiomyomas, hyperplasia of the endometrium, or endometrial cancer. The symptoms and signs of the rare virilizing GCTs are primary or secondary amenorrhea, hirsutism, clitoris hypertrophy, deepening of the voice, muscular development and acne due to elevated testosterone levels (11).

Diagnosis is based on laboratory and histopathological findings. A total of $94 \%$ of the GCTs are unilateral and diagnosed at an early stage; therefore, unilateral oophorectomy or adnexectomy as the surgical treatment is the method of choice (12). Following surgery, the majority of the symptoms resulting from hormone production may disappear. Based on the histopathological staging, adjuvant chemotherapy or radiotherapy should be considered (13). The prognosis is excellent, with 90-95\% 5-year survival in the early stages, and this correlates with tumor stage, grade and mitotic index (14). Follow-up must be performed every two to three months during the first few years following the operation, but since late recurrences have been reported 20 years after the initial treatment, long-term follow-up should also be considered (15).

In conclusion, virilizing GCTs are rare causes of hyperandrogenism in adolescents. The diagnosis is based on signs and symptoms of elevated testosterone levels, clinical and imaging findings; however, a definitive diagnosis can only be made following histopathology. The majority of the cases are discovered at an early stage; therefore, 5-year and 10-year survival rates are excellent. The tumor may be treated surgically; in the majority of the cases, without a need for postoperative adjuvant therapy; however, long-term follow up should be considered, as late recurrences are mentioned in the relevant literature.

\section{References}

1. Thrall MM, Paley P, Pizer E, Garcia R and Goff BA: Patterns of spread and recurrence of sex cord-stromal tumors of the ovary. Gynecol Oncol 122: 242-245, 2011.

2. Howlader N, Noone AM, Krapcho M, Garshell J, Miller D, Altekruse SF, Kosary CL, Yu M, Ruhl J, et al: (eds): SEER Cancer Statistics Review, 1975-2012, National Cancer Institute. Bethesda, MD, http://seer.cancer.gov/csr/1975_2012.

3. Horányi D, Koiss R, Babarczi E and Siklós P: A petefészek ivarléc-stroma eredetú daganatainak kezelésével szerzett tapasztalataink. Nógyógyászati Onkológia 16: 40-42, 2011.

4. Csapó ZS, Szirmai K, Nagy GyR and Papp Z: Granulosa cell tumor (Retrospective study of 15 cases occuring during 15 years). Magyar Nőorvosok Lapja 69: 471-474, 2006.

5. Göcze P, Krommer K, Csermely T, Cziráky K, Garamvölgyi Z, Kovács K and Szabó I: Ovulation induction therapy and ovarian cancer. Orvo Hetil 141: 71-75, 2000 (In Hungarin).

6. Tanyi J, Rigó JR, Kis Csitári I and Csapó ZS: Juvenile granulosa cell tumor complicating pregnancy: Report of 2 cases. Magyar Nőorvosok Lapja 61: 451-454, 1998.

7. Haroon S, Idrees R, Zia A, Memon A, Fatima S and Kayani N: Ovarian sex cord stromal tumours in children and young girls-a more than two decade clinicopathological experience in a developing country, Pakistan. Asian Pac J Cancer Prev 15: 1351-1355, 2014.

8. Hashemipour M, Moaddab MH, Nazem M, Mahzouni P and Salek M: Granulosa cell tumor in a six-year-old girl presented as precocious puberty. J Res Med Sci 15: 240-242, 2010.

9. Kabaca C, Karateke A, Gurbuz A and Cesur S: Androgenic adult granulosa cell tumor in a teenager: A case report and review of the literature. Int J Gynecol Cancer 16 (Suppl 1): S368-S374, 2006.

10. François Y, Berlier P, Chatelain P and François R: Virilizing ovarian tumor in an adolescent. Pediatrie 45: 105-107, 1990 (In French)

11. Patel SS, Carrick KS and Carr BR: Virilization persists in a woman with an androgen-secreting granulosa cell tumor. Fertil Steril 91: 933.e13-e15, 2009.

12. Ayhan A, Salman MC, Velipasaoglu M, Sakinci M and Yuce K: Prognostic factors in adult granulosa cell tumors of the ovary: A retrospective analysis of 80 cases. J Gynecol Oncol 20: 158-163, 2009.

13. Tai YJ, Chang WC, Kuo KT and Sheu BC: Ovarian steroid cell tumor, not otherwise specified, with virilization symptoms. Taiwan J Obstet Gynecol 53: 260-262, 2014.

14. Haroon NN, Agarwal G, Pandey R and Dabadghao P: Juvenile granulosa cell tumor presenting as isosexual precocious puberty: A case report and review of literature. Indian J Endocrinol Metab 17: 157-159, 2013.

15. Kota SK, Gayatri K, Pani JP, Meher LK, Kota SK and Modi KD: Ovarian granulosa cell tumor: An uncommon presentation with primary amenorrhea and virilization in a pubertal girl. Indian $\mathrm{J}$ Endocrinol Metab 16: 836-839, 2012. 